\title{
Supplemental linseed oil and antioxidants affect fatty acid composition, oxidation and colour stability of frozen pork
}

\author{
E. Górska-Horczyczak", I. Wojtasik-Kalinowska \& A. Wierzbicka \\ Department of Technique and Food Product Development, Institute of Human Nutrition Sciences, Warsaw University of \\ Life Sciences SGGW (WULS SGGW), Warsaw; Nowoursynowska Street 159 c, 02-776 Warsaw, Poland
}

(Received 26 November 2018; Accepted 4 January 2020; First published online 25 April 2020)
Copyright resides with the authors in terms of the Creative Commons Attribution 4.0 South African License. See: http://creativecommons.org/licenses/by/4.0/za
Condition of use: The user may copy, distribute, transmit and adapt the work, but must recognize the authors and the South African Journal of Animal Science.

\begin{abstract}
The aim of this study was to evaluate the influence of dietary linseed oil and antioxidants on the quality of fresh and frozen pork neck stored at $-20^{\circ} \mathrm{C}$ for six and 12 months. Polish Landrace $x$ Duroc pigs were fed a standard diet (C), a diet supplemented with $3 \%$ linseed oil (L1), or a diet with $3 \%$ of linseed oil, $1 \mathrm{mg}$ organic selenium (SE)/kg, and $100 \mathrm{mg}$ vitamin E/ $\mathrm{kg}$ (L2). Chemical components, fatty acid profile and vitamin $\mathrm{E}$ content were determined in the fresh meat. Colour, $\mathrm{pH}$ and change in the profiles of certain volatile compounds (alcohols, aldehydes, ketones, and esters) were monitored during frozen storage. An electronic nose technique, which was based on ultra-fast gas chromatography, was used to evaluate changes in the profiles of the volatile compounds. After six months of frozen storage, oxidative processes were slower and similar in groups L1 and L2, but less so in meat from C. In pork that was stored for six months, lipid oxidation was not affected by supplementation only with linseed oil (L1). After 12 months of frozen storage, a reduced rate of increase in alcohols, aldehydes and ketones was observed in pork from L2 relative to L1 and C. Lipid oxidation processes in long-stored frozen pork neck were inhibited by the addition of antioxidants to L2. However, a total colour change $\left(\Delta \mathrm{E}^{*}\right)$ of the pork from $\mathrm{L} 1$ and $\mathrm{L} 2$ was found during storage, which might influence consumers' decisions to purchase the product.
\end{abstract}

Keywords: colour, fatty acids, freezing, meat quality, volatile components

\#Corresponding author: Elzbieta_Gorska_Horczyczak@sggw.pl

\section{Introduction}

Pork is an important source of protein, B vitamins, and microelements, such as iron and zinc (Biesalski 2005). Pork is particularly rich in vitamin $B_{1}$, the content of which is higher than in other meats (Esteve et al., 2002; Lombardi-Boccia et al., 2005). Pork is also a source of fat soluble vitamins, especially vitamin E. Pork meat has a more beneficial ratio than beef in the sum of monounsaturated fatty acids (MUFAs) to the sum of saturated fatty acids (SFAs), and a good proportion of fatty acids n-6 to n-3 (Raes et al., 2004; De Smet et al., 2004; Saadoun \& Cabrera, 2008; Olmedilla-Alonso et al., 2013). For example, pork has a better ratio than poultry of $n-6$ to $n-3$ acids (Juárez et al., 2011; Raj et al., 2010). An n-6/n-3 ratio below 4 in the human diet is important in the prevention of cardiovascular disease, chronic inflammatory disorders, cancer and mental illness (Assisi et al., 2006; Calder, 2006; Gómez Candela et al., 2011; Harris, 2007).

The use of specially prepared feeds that improve the nutrition value of meat is important nowadays as consumers pay greater attention to pro-health values of consumed foods and require high-quality products. Pork meat with a composition of fatty acids that are beneficial to human health and that does not lose its quality during storage is therefore of interest to consumers and producers. The effect of diet on the fatty acid profile is particularly evident in monogastric animals, to which pigs belong (Raes et al., 2004). To improve the content of fatty acids in meat, feeds are used that are rich in essential fatty acids (Lu et al., 2008). But increasing the polyunsaturated fatty acid (PUFA) content may cause a deterioration in the quality of pork. Excessively high concentrations of unsaturated fatty acids (UFAs) in the diet lead to the deterioration of technological and sensory values of pork meat, because of its susceptibility to oxidation processes (Wang et al., 2012; Wood et al., 2003). These processes can be inhibited through the addition of antioxidants to feed 
(Pogorzelska-Nowicka et al., 2018). Vitamin E (mainly a-tocopherol) and selenium are natural protective factors against the oxidation of phospholipids (Kim et al., 2010).

Freezing extends the shelf life of meat, and frozen storage of meat is adopted widely by producers (Leygonie et al., 2012). However, it changes the quality of the meat (Elsbernd et al., 2016). The volatile compound profile also changes. In future the taste and odour of meat may be adjusted according to customers' requirements (Vandendriessche, 2008). It would be possible to accomplish this goal through arranging the composition of fodder, which would avoid undesirable meat taste and odour (Hernandez-Lopez et al., 2016).

Few studies show the changes that occur in pork necks with different PUFA contents during long-term frozen storage. The goal of this research was to determine the influence of bioactive swine feed additives, including antioxidant supplementation, on changes of certain properties of fresh and long-term frozen pork neck. Colour, $\mathrm{pH}$, and volatile compound profile changes in vacuum-packed pork neck that occurred during frozen storage for six and 12 months at $-20 \pm 1^{\circ} \mathrm{C}$ were analysed.

\section{Materials and Methods}

Pork necks were obtained from crossbred Polish Landrace $x$ Duroc pigs that were produced in accordance with the principles of the National Breeding Programme (POLSUS, 2017). Animals were kept in a controlled environment that guaranteed an appropriate standard of welfare with access to fresh water. The local ethical commission approved the procedures (no 27/2009).

The standard diet consisted of barley grits $(360 \mathrm{~g} / \mathrm{kg})$, wheat middlings $(360 \mathrm{~g} / \mathrm{kg})$, corn grits $(100$ $\mathrm{g} / \mathrm{kg}$ ), extracted soybean meal $(80 \mathrm{~g} / \mathrm{kg})$, extracted rapeseed meal $(40 \mathrm{~g} / \mathrm{kg})$, and premix vitamins and minerals $(25 \mathrm{~g} / \mathrm{kg})$. The first stage of fattening lasted about 2.5 months. Subsequently, 36 pigs, each weighing approximately $60 \mathrm{~kg}$ (Brodowska et al., 2016; Brodowska et al., 2018), were randomly divided into three groups and fed with the standard control diet (C), the standard diet supplemented with $3 \%$ of linseed oil (L1), and the standard diet supplemented with $3 \%$ of linseed oil and $1 \mathrm{mg} / \mathrm{kg}$ of organic selenium and 100 $\mathrm{mg} / \mathrm{kg}$ vitamin E (L2). The profile of total fatty acid composition in the linseed oil was $9.8 \% \mathrm{SFA}, 21.6 \%$ MUFA, and 68.6\% PUFA, including 60\% a-linolenic acid. In L1 and L2, $\alpha$-linolenic acid was supplied at 12.4 $\mathrm{g} / \mathrm{kg}$ of feed. Pigs were fed until they obtained $100 \pm 5 \mathrm{~kg}$ of slaughter weight (approximately six months).

Six pork necks were randomly selected from each treatment and transported to the laboratory under refrigeration $\left(3 \pm 1{ }^{\circ} \mathrm{C}\right)$. The longissimus cervicis, rhomboideus, and sternocephalicus trapezius were the main muscles in each neck. Each pork neck was cut across fibres into nine slices, about $2 \mathrm{~cm}$ thick. Three slices from each pork neck were tested on the same day, that is, 18 samples in triplicate. Six slices from each pork neck were individually vacuum-packed and frozen at $-20 \pm 1{ }^{\circ} \mathrm{C}$. Samples were subsequently evaluated after six months (18 samples in triplicate) and 12 months (18 samples in triplicate) of being frozen.

Fat, protein, water and ash content were measured with an accredited method with a Fourier transformation near-infrared spectrophotometer (NIRFlex N-500, Buchi Labortechnik AG, Flawil, Switzerland) with solids module and applications for meat. One hundred grams of homogenized sample was placed in a petri dish and tested with the application (Wyrwisz et al., 2012). Measurements were carried out in the spectral range of $12500-4000 \mathrm{~cm}^{-1}$ in reflectance mode with a resolution of $8 \mathrm{~cm}^{-1}$.

A homogenized $5 \mathrm{~g}$ sample of meat was used for lipid extraction, which was carried out according to the method of Folch et al. (1957) with chloroform/methanol $(2: 1 \mathrm{v} / \mathrm{v})$. The analysis of fatty acid methyl esters (FAME) was conducted with a gas chromatograph with a flame ionization detector (GC-7890, Agilent Technologies Inc., CA, USA). Separation was carried out on a Hewlett-Packard-88 (J\&W Columns GC, Agilent Technologies Inc., California, USA) capillary column (60 m x $0.25 \mathrm{~mm}$ inner diameter $\times 0.20 \mu \mathrm{m}$ film thickness). Helium was used as a carrier gas with a flow rate of $50 \mathrm{~mL} \mathrm{~min}^{-1}$. Gas chromatography (GC) working conditions consisted of a starting oven temperature at $140{ }^{\circ} \mathrm{C}$, then $4{ }^{\circ} \mathrm{C} \min ^{-1}$ to $190{ }^{\circ} \mathrm{C}$, then to $215^{\circ} \mathrm{C}$ at a ratio of $0.8^{\circ} \mathrm{C} \mathrm{min}^{-1}$. Detector and injector temperatures were $260{ }^{\circ} \mathrm{C}$. The volume of injection was $1 \mu \mathrm{L}$, and the split ratio was 1: 40. Supelco 37 Component FAME Mix $(1 \times 1 \mathrm{~mL}$, varied concentration in dichloromethane) (Sigma-Aldrich, St Louis, Missouri) was used for fatty acid identification.

The concentration of $\alpha$-tocopherol (type of vitamin E) in pork neck was determined according to Joźwik et al. (2013). The first stage consisted of saponification with aqueous solution potassium hydroxide. Hexane was used for extraction. Separation was performed in a reversed phase system of high-performance liquid chromatography (HPLC) with ultraviolet detection. The mobile phase was propan-2-ol in acetonitrile (17:83,

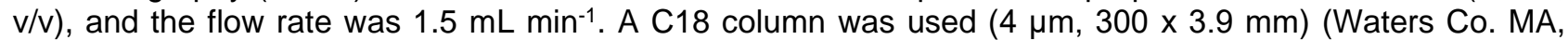
USA) with a guard-column C18 $(10 \times 6 \mathrm{~mm})$ Nova Pak, Waters Co. MA, USA) containing C18 pellicular packing material (degradation $30-40 \mu \mathrm{m}$ ).

Colour coordinates were measured with a Minolta CR-400 spectrophotometer (Konica Minolta, Inc., Tokyo, Japan) with an $8 \mathrm{~mm}$ aperture, and illuminate D65 at a standard observation of $2^{\circ}$. Calibration was performed with a white plate pattern $\left(L^{*}=98.45, a^{*}=-0.10, b^{*}=-0.13\right)$. Before being measured, the sample 
was stored in a plastic bag, away from light, at $5 \pm 1^{\circ} \mathrm{C}$. Each sample was removed from its plastic bag and placed on a cotton cloth. After 20 minutes the colour was measured and the slice was inverted. After another 20 minutes the colour was measured again. The optimal bloom time for pork is 20 min (Brewer et al., 2001). In this period, the colour of pork meat stabilizes. For each sample, colour was measured at five locations on each side of the slice. Differences between colours were assessed with the colour difference coefficient $\left(\Delta \mathrm{E}^{*}\right)$ according to the equation:

$$
\Delta E^{*}=\sqrt{\left(L_{1}^{*}-L_{i}^{*}\right)^{2}+\left(a_{1}^{*}-a_{i}^{*}\right)^{2}+}\left(b_{1}^{*}-b_{i}^{*}\right)^{2}
$$

where the subscripts 1 and i designate measurements from fresh and frozen pork, respectively (Wyrwisz et al., 2012).

A Testo 205 one-hand $\mathrm{pH} /{ }^{\circ} \mathrm{C}$ measuring instrument (Testo AG, Lenzkirch, Germany), equipped with an insertion glass electrode and automatic temperature compensation, was used to measure $\mathrm{pH}$. Calibration was carried out with standard buffer solutions at $\mathrm{pH} 4.01$ and 7.00 .

Volatile compound profiles of the pork necks were measured with a fast solvent-less method with an electronic nose (Górska-Horczyczak et al., 2017) to verify whether the diets influenced these profiles. The Heracles II (Alpha MOS Co., Toulouse, France) e-nose was used, which is based on ultra-fast gas chromatography (UFGC), with headspace. The UFGC unit was equipped with two polarity capillary columns (MXT-5 and MXT-1701, $10 \mathrm{~m} \times 0.18 \mathrm{~mm}$ ID $\times 0.4 \mu \mathrm{m}$ film thickness). Hydrogen was used as a carrier gas with a flow rate of $10 \mathrm{~mL} / \mathrm{min}^{-1}$. The oven temperature started at $40{ }^{\circ} \mathrm{C}$. After five seconds it was increased by $4^{\circ} \mathrm{C} / \mathrm{s}$ to $270{ }^{\circ} \mathrm{C}$, which was maintained for 30 seconds. Detector and injector temperatures were $270{ }^{\circ} \mathrm{C}$. The samples of pork neck were approximately $2.5 \mathrm{~g}$, and the feed samples were approximately $1 \mathrm{~g}$. Twentymillilitre vials with samples were incubated at $55^{\circ} \mathrm{C}$ for 15 minutes. The volume of injection was $3500 \mu \mathrm{L}$. Kovats indexes were calculated for two columns and AroChemBase library was used to identify volatile compounds, which was carried automatically with Heracles II AlfaSoft software. A standard mixture of C6C16 alkanes (Restek, ANCHEM Plus, Warszawa, Poland) was used. Retention indices were confirmed based on the standards of test substances. The tests were conducted in triplicate.

Statistica software version 12 (StatSoft Inc., Tulsa, Oklahoma, USA) was used for statistical analysis of the physicochemical data of pork neck. Normality of the data was tested using the Shapiro-Wilk test. Statistical analyses were performed using analysis of variance (ANOVA) and post-hoc Tukey's test. The results of the chemical composition in fresh meat and relative changes in volatile compounds in the three feeding groups were analysed using one-way ANOVA. The $\mathrm{pH}$ results and changes in the $L^{*} a^{*} b^{*}$ coordinates during storage were analysed by one-way ANOVA for repeated measures. The significance level was set to $\alpha \leq 0.05$. A statistical package (AlfaSoft, delivered with Heracles II) with statistical quality control was used to perform comparative analysis and evaluate the chromatographic fingerprint of the volatile compounds.

\section{Results and Discussion}

Chemical composition $\left(\mathrm{mg} \cdot \mathrm{g}^{-1}\right)$, total fatty acid profile and vitamin $\mathrm{E}$ content $\left(\mu \mathrm{g} \cdot \mathrm{g}^{-1}\right)$ of fresh pork neck samples from the three treatments are presented in the Table 1 . Significant $(P<0.05)$ differences in percentages of moisture, fat and protein were found. Pork from C and L2 differed significantly from L1. Brodowska et al. $(2016,2018)$ found the lowest fat content and greatest moisture and protein contents in pork loins from pigs whose diet was enriched with 3\% linseed oil. Skoufos et al. (2016) reported decreased crude fat and increased moisture and crude protein meat from pigs that were fed diets that contained extruded rapeseed meal compared with pigs fed soybean meal-based diets.

Meat from L2 had an increased $(P<0.05)$ percentage of PUFAs compared with $C$ and $L 1$. The main PUFA of linseed oil is C18:3n-3 or a-linolenic acid (Jiang et al., 2017), and pigs fed L1 and L2 had significant increases in a-linolenic acid in their meat compared with $\mathrm{C}$.

The highest vitamin $E$ content was observed in meat from L2, while the lowest was observed for L1, with the control being intermediate. Adding only linseed oil to the standard control diet might decrease the vitamin $\mathrm{E}$ content, because vitamin $\mathrm{E}$ is used to protect against oxidation of UFAs. In the current study, L2 was supplemented with the antioxidants, vitamin $\mathrm{E}$ and selenium. Together they have a synergistic effect. However, each has a different action mechanism. Selenium is a component of enzymatic proteins, inter alia, glutathione peroxidase, which neutralizes free radicals. Therefore, it protects lipids against peroxidation and UFAs against oxidation. Vitamin E, on the other hand, belongs to the non-enzymatic small-molecule antioxidants and neutralizes secondary radicals. The literature indicated that selenium might influence vitamin $\mathrm{E}$ regeneration in biological systems and increase their antioxidant properties ( $\mathrm{Li}$ et al., 2001; Venkateswaran et al., 2004). 
Table 1 Effect of diet supplementation with linseed oil, vitamin E and selenium on chemical composition, fatty acid content and vitamin $\mathrm{E}$ content of fresh pork neck

\begin{tabular}{|c|c|c|c|}
\hline Parameters & Control diet & $\begin{array}{l}\text { Diet supplemented with } 3 \% \\
\text { linseed oil }\end{array}$ & $\begin{array}{l}\text { Diet supplemented with } 3 \% \\
\text { linseed oil, } 1 \mathrm{mg} \text { selenium, } \\
\text { and } 100 \mathrm{mg} \text { vitamin E }\end{array}$ \\
\hline \multicolumn{4}{|c|}{ Basic composition mg/g } \\
\hline Fat & $16.5^{\mathrm{a}} \pm 0.8$ & $10.3^{b} \pm 0.2$ & $15.3^{a} \pm 0.6$ \\
\hline Protein & $17.4^{a} \pm 0.2$ & $19.8^{b} \pm 0.1$ & $17.9^{\mathrm{a}} \pm 0.2$ \\
\hline Moisture & $63.8^{a} \pm 0.7$ & $68.4^{b} \pm 0.3$ & $64.8^{a} \pm 0.5$ \\
\hline \multicolumn{4}{|c|}{ Percentage total fatty acid } \\
\hline C18:2n-6 & $9.1^{\mathrm{a}} \pm 0.2$ & $9.2^{\mathrm{a}} \pm 0.1$ & $10.4^{b} \pm 0.2$ \\
\hline C18:3n-3 & $1.4^{a} \pm 0.04$ & $3.3^{b} \pm 0.04$ & $4.8^{c} \pm 0.05$ \\
\hline SFA & $47.3 \pm 0.3$ & $47.1 \pm 0.2$ & $45.9 \pm 0.6$ \\
\hline PUFA & $12.6^{a} \pm 0.2$ & $13.2^{\mathrm{a}} \pm 0.1$ & $14.9^{b} \pm 0.3$ \\
\hline MUFA & $40.1 \pm 0.5$ & $39.7 \pm 0.3$ & $39.2 \pm 0.4$ \\
\hline Vitamin E $\mu \mathrm{g} / \mathrm{g}$ & $2.78^{a} \pm 0.04$ & $2.46^{b} \pm 0.00$ & $3.12^{c} \pm 0.03$ \\
\hline
\end{tabular}

SFA: saturated fatty acids, PUFA: polyunsaturated fatty acids, MUFA: monounsaturated fatty acids

a,b,c Within a row, means with a common superscript do not differ significantly $(P<0.05)$

Dietary treatment $(P<0.01)$ and storage time $(P=0.02)$ influenced the $\mathrm{pH}$ of meat from the pork neck. However, their interaction was not significant $(P>0.10)$. After six months of storage, significant differences were found in the $\mathrm{pH}$ of pork from pigs fed $\mathrm{C}$ and those fed L1 and L2 (Table 2). There were no significant changes in the $\mathrm{pH}$ of pork neck meat from $\mathrm{C}$ and $\mathrm{L} 2$ throughout the 12 months of frozen storage. There was a clear increase in $\mathrm{pH}$ during frozen storage of the pork neck from pigs fed L1. The highest contents of protein and moisture were also observed in this group. Since the storage temperature was $-20 \pm 1{ }^{\circ} \mathrm{C}$, it is possible that a portion of unfrozen water, which was greater than in pork from pigs fed C and L2, was available for biochemical reactions (Leygonie et al., 2012). Denaturation and enzymatic hydrolysis of muscle proteins result in an increased concentration of nitrogen compounds, which leads to an increase in $\mathrm{pH}$ (Wang et al., 2012).

Colour is one of the main attributes of meat quality (Juncher et al., 2001). Wide variations were observed in the $L^{*}, a^{*}$, and $b^{*}$ values. This result is typical of dark muscles such as necks (Sevon-Aimonen et al., 2007). The interaction of dietary treatment with storage time affected $(P=0.01) L^{*}$. However, no significant effects were found for a. $\mathrm{B}^{*}$ was influenced by dietary treatment $(P<0.01)$ and storage time $(P$ $<0.01$ ) independent of each other. Meat from $C$ was significantly darker (greater $L^{*}$ values) after six and 12 months of storage at $-20 \pm 1{ }^{\circ} \mathrm{C}$ than pork neck from L1 and L2. Meat from L1 was lighter in colour after six and 12 months of frozen storage. The greater colour stability of meat from L2 compared with L1 could have been because the additions of vitamin $\mathrm{E}$ and selenium protected against for example haemoglobin autooxidation (Jensen et al., 1997). These relationships were confirmed by monitoring total colour change, $\Delta \mathrm{E}$, calculated separately for each treatment for fresh pork and frozen pork that was stored for six and 12 months. The least change of colour was observed in C. Clear colour differences were found in L2 after 12 months of frozen storage and in L1 for both periods of frozen storage. 
Table 2 Effect of diet supplementation with linseed oil, vitamin $\mathrm{E}$ and selenium on $\mathrm{pH}$ and colour of fresh and frozen-stored pork neck

\begin{tabular}{|c|c|c|c|}
\hline Attribute & Control diet & $\begin{array}{l}\text { Diet supplemented } \\
\text { with } 3 \% \text { linseed oil }\end{array}$ & $\begin{array}{l}\text { Diet supplemented with } 3 \% \\
\text { linseed oil, } 1 \mathrm{mg} \text { selenium, and } \\
100 \mathrm{mg} \text { vitamin } \mathrm{E}\end{array}$ \\
\hline \multicolumn{4}{|l|}{$\mathrm{pH}$} \\
\hline 1 day & $5.95 \pm 0.04$ & $5.74^{\mathrm{A}} \pm 0.06$ & $6.04 \pm 0.06$ \\
\hline 6 months & $5.96^{a} \pm 0.01$ & $6.13^{\mathrm{abB}} \pm 0.03$ & $6.20^{b} \pm 0.03$ \\
\hline 12 months & $5.83 \pm 0.07$ & $6.03^{B} \pm 0.05$ & $6.09 \pm 0.02$ \\
\hline \multicolumn{4}{|l|}{$L^{*}$} \\
\hline 1 day & $49.34 \pm 0.28$ & $49.7^{A} \pm 0.36$ & $47.47 \pm 0.53$ \\
\hline 6 months & $50.17^{a} \pm 0.26$ & $45.75^{\mathrm{bB}} \pm 0.60$ & $45.44^{b} \pm 0.42$ \\
\hline 12 months & $50.03^{a} \pm 0.34$ & $46.21^{\mathrm{bB}} \pm 0.25$ & $45.24^{b} \pm 0.36$ \\
\hline \multicolumn{4}{|l|}{$a^{*}$} \\
\hline 1 day & $18.25 \pm 0.84$ & $16.57 \pm 0.46$ & $16.73 \pm 0.61$ \\
\hline 6 months & $17.63 \pm 0.53$ & $17.57 \pm 0.29$ & $17.21 \pm 0.38$ \\
\hline 12 months & $18.87 \pm 0.60$ & $17.74 \pm 0.59$ & $18.43 \pm 0.66$ \\
\hline \multicolumn{4}{|l|}{$b^{*}$} \\
\hline 1 day & $8.50 \pm 0.43$ & $6.47 \pm 0.16$ & $6.49 \pm 0.22$ \\
\hline 6 months & $9.91 \pm 0.39$ & $7.90 \pm 0.18$ & $8.00 \pm 0.17$ \\
\hline 12 months & $10.54 \pm 0.43$ & $8.00 \pm 0.32$ & $8.92 \pm 0.47$ \\
\hline \multicolumn{4}{|l|}{$\Delta \mathrm{E}^{*}$} \\
\hline 6 months & 1.75 & 4.32 & 2.58 \\
\hline 12 months & 2.24 & 3.99 & 3.71 \\
\hline
\end{tabular}

$\mathrm{L}^{*}$ : lightness, $\mathrm{a}^{*}$ : redness, $\mathrm{b}^{*}$ : yellowness, $\Delta \mathrm{E}^{*}$ : total colouration of stored samples relative to fresh meat a,b,c Within a row, means with a common superscript do not differ significantly $(P<0.05)$

$\mathrm{A}, \mathrm{B}, \mathrm{C}$ Within a column, means with a common superscript do not differ significantly $(P<0.05)$

The composition of volatile compounds is thought to be a primary indicator of the overall quality of meat (Bryhni et al., 2002). Three groups of compounds, namely alcohols with aldehydes, ketones and esters, were monitored to investigate the main changes in volatile compounds that occurred during frozen storage of the pork necks. The main compounds that were found in both the feed and meat were aldehydes. However, these were similar across the dietary treatments. Significant differences were observed in the contents of alcohols, esters and nitrogen compounds. Alcohols were twice as high in L1 as in C. Lipid oxidation results in the formation of alcohols (Martin et al., 2009). The L1 diet, which was supplemented with linseed oil, but not with antioxidants, was most vulnerable to oxidation. Terpenes (pinene, myrcene, cymene) were found in all of the rations. These came from natural ingredients. Of the terpenes that are present in feed, only 1R-(+)-alpha-pinene was the found in samples of fresh pork neck and in those that were thawed after six months of frozen storage. The lowest amounts of volatile compounds were found in the fresh pork necks, with propanal and 2-methylpropanal (aldehydes), propanol (alcohol), ethyl acetate (ester), nonane (hydrocarbon) and alpha-pinene (terpene) being found across all treatments. Methylbutanoate (ester) was found only in pork neck from L1. In addition, butan-2-one (keton) and nonane (hydrocarbon) were found in the meat from L1 and L2. Some of these compounds can indicate the freshness of meat, for example ethyl acetate, which decreases during storage (Sun et al., 2017). 
Table 3 Relative area under curve of volatile compounds detected in control diet, diet supplemented with linseed oil, and diet supplemented with linseed oil, selenium and vitamin E for feeding pigs

\begin{tabular}{lrrr}
\hline Groups & Control feed & $\begin{array}{c}\text { Feed supplemented with 3\% } \\
\text { linseed oil }\end{array}$ & $\begin{array}{c}\text { Feed supplemented } \\
\text { with 3\% linseed oil, } 1 \text { mg } \\
\text { selenium, and 100 mg vitamin } \\
\text { E }\end{array}$ \\
\hline Aldehydes & $79.1 \pm 2.1$ & $84.4 \pm 1.7$ & $79.2 \pm 2.7$ \\
Nitrogen compounds & $3.0^{\mathrm{a}} \pm 0.11$ & $1.4^{\mathrm{b}} \pm 0.07$ & $1.9^{\mathrm{b}} \pm 0.09$ \\
Terpenes & $1.6 \pm 0.07$ & $1.8 \pm 0.09$ & $1.9 \pm 0.07$ \\
Alcohols & $0.6^{\mathrm{a}} \pm 0.05$ & $1.4^{\mathrm{b}} \pm 0.02$ & $\mathrm{ND}$ \\
Esters & $0.5^{\mathrm{a}} \pm 0.07$ & $0.3^{\mathrm{a}} \pm 0.02$ & $1.7^{\mathrm{b}} \pm 0.07$ \\
Volatile acids & $0.9 \pm 0.07$ & $\mathrm{ND}$ & $\mathrm{ND}$ \\
Ketones & $\mathrm{ND}$ & $\mathrm{ND}$ & $0.3 \pm 0.02$ \\
\hline
\end{tabular}

ND: not determined

a,b,c Within a row, means with a common superscript do not differ significantly $(P<0.05)$

After six months of frozen storage, the number of volatile compounds increased in all of the groups. The volatile compound profile changes during storage as a result of lipid oxidation, autolytic enzymatic breakdown of proteins and microbial processes (Meinert et al., 2008; Wettasinghe et al., 2001). Aldehydes are the main product of autoxidation (Morrissey et al., 1998) and were prominent in all of the diets. However, the increase in aldehydes in long-term frozen stored pork neck was less than the increase in alcohols. Alcohols are products of oxidative decomposition of lipids (del Olmo et al., 2014). They are also produced as a result of reduction of aldehydes and methyl-ketones owing to the activity of microorganisms (Shi et al., 2019). The main product of lipid peroxidation is malondialdehyde, while 1-propanol might be one of its main precursors. Colville et al. (2012) found a high positive correlation (0.72) of alcohols with lipid oxidation. In the current study, 1-propanol was identified in fresh meat from all three treatments, and its content increased nearly twofold after six months of frozen storage. The largest increases of alcohols in pork neck were observed in meat from C after six- and 12-months' storage. However, meat from the pork necks of L1 and L2 also increased in the content of alcohols after six months storage, although at a lower rate than the control. After 12 months of storage, meat from L1 and L2 had alcohol contents about 1.5 and 2 times smaller than group C, respectively, and were significantly different. The addition of linseed oil to feed did not affect the volatile compound profile of pork neck negatively and did not speed up alcohol production during long-term frozen storage. However, after 12 months in frozen storage the alcohol content in meat from L2 was $50 \%$ of that in meat from diet $\mathrm{C}$ and $71 \%$ of that in meat from L1.

As a result of lipid peroxidation in the presence of free radicals, PUFAs are oxidized, with aldehydes being the primary product of that process, which is reflected in the positive changes in the relative areas shown in Figure 1, particularly for meat from $\mathrm{C}$ and L1. Ketones are created as a result of oxidation as well (Nurjuliana et al., 2011). Antioxidants inhibit lipid oxidation (Feng \& Ahn, 2016). In this study, after six months of storage, significant differences were observed in the contents of aldehydes and ketones between meat from $\mathrm{C}$ and L1 and L2 $(P<0.05)$, which were similar. Observed increases of aldehydes and ketones in meat from L1 and L2 after 12 months storage were $71 \%$ and $30 \%$, respectively, in comparison with the meat from C. The observed increase in aldehydes and ketones in L2 was $43 \%$ of that of L1. Compared with the changes in the alcohol and aldehyde and ketone groups, the changes in the esters during storage were small. The dynamics of the aldehydes, alcohols, and esters during frozen storage of pork neck are shown in Figure 1. Changes were calculated separately, relative to the peak area of fresh meat for each dietary treatment. 


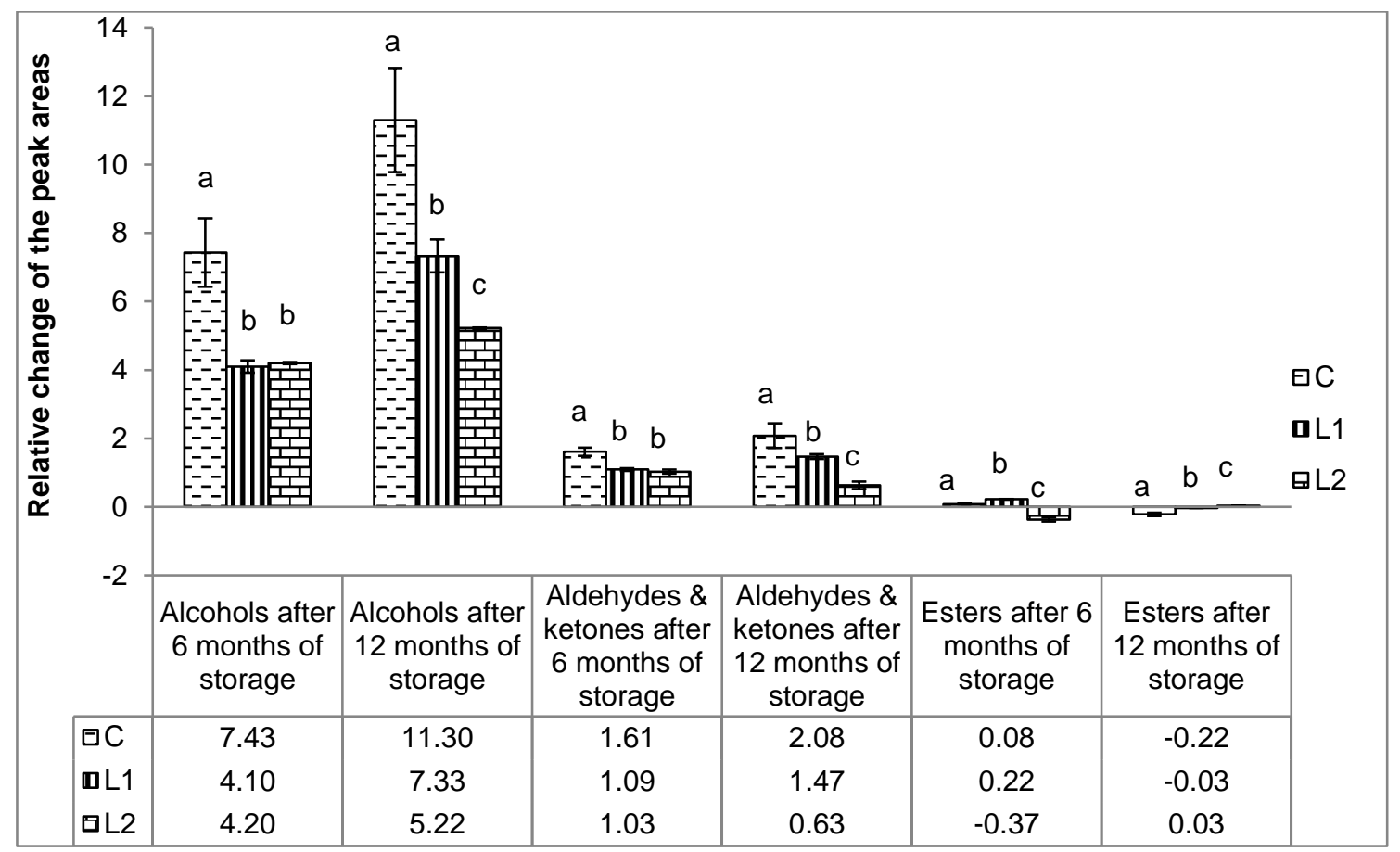

Figure 1 Relative change in peak areas of the three main groups of volatile compounds: alcohols, aldehydes and ketones, esters, during frozen storage at $-20 \pm 1^{\circ} \mathrm{C}$ for six and 12 months relative to fresh pork

C: control diet, L1: diet supplemented with $3 \%$ linseed oil, L2: diet supplemented with $3 \%$ linseed oil, 1 mg selenium and $100 \mathrm{mg}$ vitamin $\mathrm{E}$.

a,b,c Within a group, bars headed by a common superscript do not differ significantly $(P<0.05)$

Esters form during the enzymatic esterification of fatty acids and alcohols (del Olmo et al., 2014). Esters can also be a product of reduction of aldehydes (Leroy et al., 2009). After six months of storage, the ester content in pork necks from C and L1 increased but decreased in samples from L2. However, after 12 months storage, the ester contents in meat from $\mathrm{C}$ and L1 were reduced, but in samples from L2 they had increased. Teye et al. (2006) concluded that a high dietary level of vitamin $E(250 \mathrm{mg} / \mathrm{kg})$ may have prevented increased lipid oxidation in pork meat. In the current study, a lower level of vitamin $E$ was used (100 mg/kg diet), but with additional protection provided by organic selenium (1 mg/kg diet). The current research showed that supplementing the diet with linseed oil, which is high in PUFAs, did not have a negative effect on the volatile compound profile of frozen neck stored for six months. Brodowska et al. (2018) also observed that the addition of linseed oil to the ration for pigs had no influence on the volatile compounds in longissimus dorsi after nine months' frozen storage. However, in the current study, antioxidant supplementation was needed to slow lipid oxidation processes in pork neck for 12 months of frozen storage. Thus, it is recognized that supplementing diets with selenium inhibits lipid oxidation and protects against degradation of PUFAs (Zhang et al., 2011).

Differences in the volatile compound profile between the fresh and the frozen pork necks were small in comparison with the diets. Profiles of L1 and L2 were similar, but different from that of $\mathrm{C}$. The profiles changed considerably in the samples of meat that were thawed after six months of frozen storage. After six months of storage, dimethyl sulphide appeared in all treatments. The profile of the control diet (excluding one sample (random element)) and that of L2, which was enriched in bioactive substances, were similar. However, the profile meat from L1 showed large internal scatter in a range of -30 to +40 units. Differences in volatile compound profiles after 12 months of frozen storage increased twofold in comparison with changes after six months. In volatile compound profiles, dimethyl sulphide, dimethyl disulphide, and trimethylamine appeared with 12 months of frozen storage and terpenes disappeared. Dimethyl sulphide and dimethyl disulphide are products of the conversion of amino acids (methionine, cysteine and cystine) to thiols as a result of microbial activity (Casaburi et al., 2015). Trimethylamine, an alkaline chemical like ammonia, is an aliphatic biogenic monoamine that can be an indicator of meat spoilage (Xiao-Wei et al., 2016). Its production is also connected to microbial activity and causes an increase of $\mathrm{pH}$ of meat (Djordjević et al., 2018). Figure 2 presents a statistical quality control chart of differences in volatile compound profiles during sample storage. The data represent odour distances that were measured as Euclidian distance. The grey 
area in the chart, with a range of -15 to +15 units, provides a reference odour profile relative to the fresh sample (1 day).

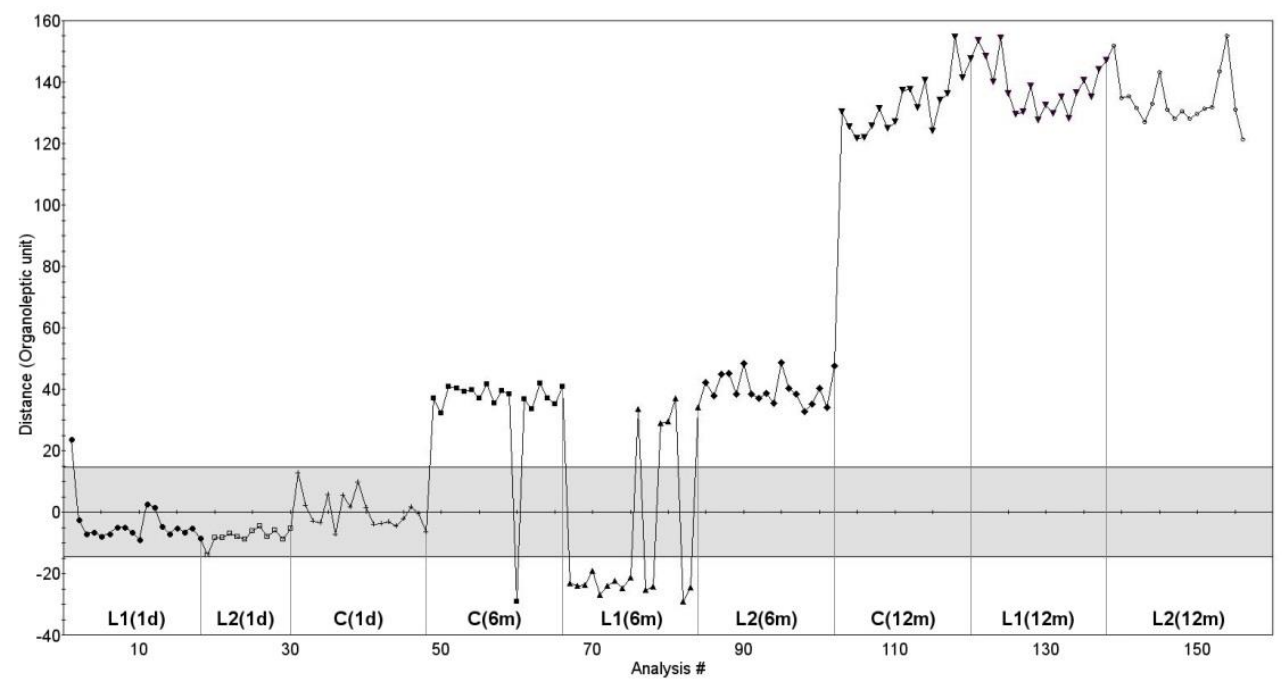

Figure 2 Chromatographic profiles of fresh pork necks (1 day), pork necks thawed after six months ( $6 \mathrm{~m}$ ) and after 12 months $(12 \mathrm{~m})$ of frozen storage at $-20 \pm 1^{\circ} \mathrm{C}$

C: control diet, L1: diet supplemented with $3 \%$ linseed oil, L2: diet supplemented with $3 \%$ linseed oil, 1 mg selenium and $100 \mathrm{mg}$ vitamin $\mathrm{E}$.

\section{Conclusions}

Diets supplemented with linseed oil increased the content of PUFAs in pork neck. Colour changes during long-term frozen storage were greater in the supplemented groups than in the control, with linseed oil supplementation darkening the meat. This darkening may adversely affect the decisions of consumers to purchase the product. Observed changes in alcohols, aldehydes and ketones showed that the diet could be supplemented with linseed oil alone and not adversely affect pork that was intended for up to six months of frozen storage. The slower increase in volatile compounds in pork from L1 and L2 may indicate a reduced rate of oxidation compared with the meat from $\mathrm{C}$. The addition of antioxidants to the diet supplemented with linseed oil, namely L2, had positive effects in slowing oxidation in meat stored for 12 months. The use an electronic nose to measure volatile compounds is proposed to monitor oxidation changes in frozen stored meat. It is possible to use this method for fast assessment of pork oxidation processes.

\section{Acknowledgements}

This research was financially supported by Polish Ministry of Science and Higher Education within funds of Faculty of Human Nutrition and Consumer Sciences, Warsaw University of Life Sciences (WULS-SGGW), for scientific research. Research was realized within a BIOFOOD innovative, functional products of animal origin no. POIG.01.01.02014-090/09 co-financed by the European Union from the European Regional Development Fund within the Innovative Economy Operational Programme 2007-2013.

\section{Authors' Contributions}

EGH was responsible for the concept, formulation of objectives and scope of research, formulation of conclusions, and creation of the publication text. IWK co-conducted the tests, and provided linguistic corrections. AW provided scientific consultation and final approval.

\section{Conflict of Interest Declaration}

The authors declare that they have no competing interests.

\section{References}

Assisi, A., Banzi, R., Buonocore, C., Capasso, F., Muzio, V.D., Michelacci, F., Renzo, D., Tafuri, G., Trotta, F., Vitocolonna, M. \& Garattini, S., 2006. Fish oil and mental health: The role of $n-3$ long-chain polyunsaturated fatty 
acids in cognitive development and neurological disorders. Int. Clin. Psychopharm. 21, 319-336. DOI: 10.1097/01.yic.0000224790.98534.11

Biesalski, H.K., 2005. Review Meat as a component of a healthy diet - are there any risks or benefits if meat is avoided in the diet? Meat Sci. 70, 509-524.

Brewer, M.S., Zhu, L.G., Bidner, B., Meisinger, D.J. \& McKeith, F.K., 2001. Measuring pork color: effects of bloom time, muscle, $\mathrm{pH}$ and relationship to instrumental parameters. Meat Sci. 57, 169-176.

Brodowska, M., Guzek, D., Godziszewska, J., Pogorzelska, E. \& Wierzbicka, A., 2018. Oxidation processes of Longissimus dorsi from pigs supplemented with oil and antioxidants. S. Afr. J. Anim. Sci. 48(3), 545-552.

Brodowska, M., Guzek, D., Kołota, A., Głąbska, D., Górska-Horczyczak, E., Wojtasik- Kalinowska, I. \& Wierzbicka, A., 2016. Effect of diet on oxidation and profile of volatile compounds of pork after freezing storage. J. Food Nutr. Res. 55(1), 40-47.

Bryhni, E. A., Byrne, D. V., Rodbotten, M., Claudi-Magnussen, C., Agerhem, H. \& Johansson, M., 2002. Consumer perceptions of pork in Denmark, Norway and Sweden. Food Qual. Prefer. 13, 257-266. DOI.org/10.1016/S09503293(02)00021-6

Calder, P.C., 2006. n-3 polyunsaturated fatty acids, inflammation, and inflammatory diseases. Am. J. Clin. Nutr. 83, 1505S-1519S. DOl.org/10.1093/ajcn/83.6.1505S

Casaburi, A., Piombino, P., Nychas, G.J., Villani, F. \& Ercolini, D., 2015. Bacterial populations and the volatilome associated to meat spoilage. Food Microbiol. 45, 83-102.

Cheah, K.S., Cheah, A.M. \& Krausgrill, D.I., 1995. Effect of dietary supplementation of vitamin E on pig meat quality. Meat Sci. 39, 255-264.

Colville, L., Bradley, E.L., Lloyd, A.S., Hugh, W., Castle, L. \& Kranner, I., 2012. Volatile fingerprints of seeds of four species indicate the involvement of alcoholic fermentation, lipid peroxidation, and Maillard reactions in seed deterioration during ageing and desiccation stress. J. Exp. Bot. 63(18), 6519-6530.

Custódioa, F.B., Vasconcelos-Neto, M.C., Theodoroa, K.H., Chisté, R.C. \& Gloriaa M.B.A., 2018. Assessment of the quality of refrigerated and frozen pork by multivariate exploratory techniques. Meat Sci. 139, 7-14.

De Smet, S., Raes, K. \& Demeyer, D., 2004. Meat fatty acid composition as affected by fatness and genetic factors: a review. Anim. Res. 53, 81-98. DOI: 10.1051/animres:2004003

Del Olmo, A., Calzada, J. \& Ninez, M., 2014. Effect of high-pressure processing and modified-atmosphere-packing on the volatile compounds and odour characteristics of sliced ready-to-eat 'lacon', a cured-cooked pork meat product. Innov. Food Sci. Emerg. 26, 134-142. DOI.org/10.1016/j.ifset.2014.03.003

Djordjević, J., Bosković, M., Starcević, M. Ivanović, J., Karabasil, N., Dimitrijević, M., Branković, Lazić, I. \& Baltić, M.Z., 2018. Survival of Salmonella spp. in minced meat packaged under vacuum and modified atmosphere. Braz. J. Microbiol. (in press). https://doi.org/10.1016/j.bjm.2017.09.009

Elsbernd, A.J., Patience, J.F. \& Prusa, K.J., 2016. A comparison of the quality of fresh and frozen pork from immunologically castrated males versus gilts, physical castrates, and entire males. Meat Sci. 111, 110-115.

Esteve, M.J., Farré, R., Frígola, A. \& Pilamunga, C., 2002. Contents of vitamins B1, B2, B6, and B12 in pork and meat products. Meat Sci. 62, 73-78.

Feng, X. \& Ahn, D.U., 2016. Volatile profile, lipid oxidation and protein oxidation of irradiated ready-to-eat cured turkey meat products. Radiat. Phys. Chem. 127, 27-33.

Folch, J., Lee, M. \& Sloane Stanley, G.H., 1957. A simple method for the isolation and purification of total lipids from animal tissues. J. Biol. Chem. 22, 226-497.

Gómez Candela, C., Bermejo López, L. M. \& Loria Kohen, V., 2011. Importance of a balanced omega 6/omega 3 ratio for the maintenance of health. Nutritional recommendations. Nutr. Hosp. 26, 323-329. DOI:10.3305/nh.2011.26.2.5117

Górska-Horczyczak, E., Wojtasik-Kalinowska, I. Guzek, D., Sun, D.-W. \& Wierzbicka, A., 2017. Differentiation of chillstored and frozen pork necks using electronic nose with ultra-fast gas chromatography. J. Food Process Eng. 40, $1-9$.

Harris, W.S., 2007. Omega-3 fatty acids and cardiovascular disease: A case for omega-3 index as a new risk factor. Pharmacol. Res. 55, 217-233. DOI.org/10.1016/j.phrs.2007.01.013

Hernandez-Lopez, S.H., Rodrıguez-Carpena, J.G, Lemus-Flores, C., Galindo-Garcıa, J. \& Estevez, M., 2016. Antioxidant protection of proteins and lipids in processed pork loin chops through feed supplementation with avocado. J. Food Sci. Technol. 53(6), 2788-2796.

Jensen, C., Guider, J., Skovgaar, I.M., Staun, H., Skibsted, L.H., Jensen, S. K., Møller, A.J., Buckley, J. \& Bertelsen, G., 1997. Effects of dietary $\alpha$-tocopheryl acetate supplementation on $\alpha$-tocopherol deposition in porcine $m$. psoas major and $\mathrm{m}$. longissimus dorsi and on drip loss, colour stability and oxidative stability of pork meat. Meat Sci. 45(4), 491-500.

Jiang, J., Tang, X., Xue, Y., Lin, G. \& Xiong, L., 2017. Dietary linseed oil supplemented with organic selenium improved the fatty acid nutritional profile, muscular selenium deposition, water retention, and tenderness of fresh pork. Meat Sci. 131, 99-106. DOI.org/10.1016/j.meatsci.2017.03.014

Joźwik, A., Poławska, E., Strzałkowska, N., Niemczuk, K., Łysek-Gładysińska, M., Kamińska, A. \& Michalczuk, M., 2013. Effect of linseed, rapeseed, and vitamin E long term supplementation on the activity of the lysosomal enzymes in ostrich liver. B. Vet. I. Pulawy. 57, 573-578.

Juárez, M., Michael, E.R. Dugan, M.E.R., Aalhus, J.L., Aldai, N., Basarab, J.A., Baron, V.S. \& McAllister, T.A., 2011. Effects of vitamin $\mathrm{E}$ and flaxseed on rumen-derived fatty acid intermediates in beef intramuscular fat. Meat Sci. 88, 434-440. 
Juncher, D., Rønn, B., Mortensen, E., Henckel, P., Karlsson, A., Skibsted, L. \& Bertelsen, G., 2001. Effect of preslaughter physiological conditions on the oxidative stability of colour and lipid during chill storage of pork. Meat Sci. 58(4), 347-357. DOI.org/10.1016/S0309-1740(00)00156-X

Kim, Y.J., Park, W.Y. \& Choi, I.H., 2010. Effects of dietary $\alpha$-tocopherol, selenium, and their different combinations on growth performance and meat quality of broiler chickens. Poult. Sci. 89, 603-608. DOI.org/10.3382/ps.200900280

Kouba, M., Enser, M., Whittington, F.M., Nute, G. R. \& Wood, J.D., 2003. Effect of a high-linolenic acid diet on lipogenic enzyme activities, fatty acid composition, and meat quality in the growing pig. Anim. Sci. J. 81, 1967-1979.

Leroy, F., Vasilopoulos, C., Van Hemelryck, S., Falcony, G. \& De Vuyst, L., 2009. Volatile analysis of spoiled, artisantype, modified-atmosphere-packaged cooked ham stored under different temperatures. Food Microbiol. 26, 94102.

Leygonie, C., Britz, T.J. \& Hoffman, L.C., 2012. Impact of freezing and thawing on the quality of meat: Review. Meat Sci. 91, 93-98.

Li, X., Hill, K.E., Burk, R.F. \& May, J.M., 2001. Selenium spares ascorbate and $\alpha$-tocopherol in cultured liver cell lines under oxidant stress. FEBS Letters, 508, 489-492

Lombardi-Boccia, G., Lanzi, S. \& Aguzzi, A., 2005. Aspects of meat quality: trace elements and B vitamins in raw and cooked meats. J. Food Compos. Anal. 18, 39-46.

Lu, P., Zhang, L.Y., Yin, J.D, Everts, A.K.R. \& Li, D.F., 2008. Effects of soybean oil and oil on fatty acid compositions of muscle lipids and cooked pork flavour. Meat Sci. 80, 910-918.

Martin, D., Antequera, T., Muriel, E., Perez-Palacios, T. \& Ruiz, J., 2009. Volatile compounds of fresh and dry-cured loin as affected by dietary conjugated linoleic acid and monounsaturated fatty acids. Meat Sci. 81(3), 549-556. https://doi.org/10.1016/j.meatsci.2008.10.010

Meinert, L., Tikk, K., Tikk, M., Brockhoff, P.B., Bejerholm, C. \& Aaslyng, M.D., 2008. Flavor formation in pork semimembranosus: Combination of pan-temperature and raw meat quality. Meat Sci. 80, 249-258. DOI: 10.1016/j.meatsci.2007.11.029

Morrissey, P.A., Sheehy, P.J.A., Galvin, K., Kerryh, J.P. \& D. J. Buckleyh, D.J., 1998. Lipid stability in meat and meat products. Meat Sci., 49(Suppl. I), S73 S86. DOI.org/10.1016/S0309-1740(98)90039-0

Mourot, J. \& Hermier, D., 2001. Lipids in monogastric animal meat. Reprod. Nutr. Dev, 41, 109-118.

Ngapo, T.M., Martin, J.F. \& Dransfield, E., 2007. International preferences for pork appearance: I. Consumer choices. Food Qual. Prefer. 18, 26-36.

Nurjuliana, M., Che Man, Y.B., Hashim, D.M. \& Mohamed, A.K.S., 2011. Rapid identification of pork for halal authentification using the electronic nose and gas chromatography mass spectrometer with headspace analyzer. Meat Sci. 88, 638-644.

Olmedilla-Alonso, B., Jiménez-Colmenero, F. \& Sánchez-Muniz, F.J., 2013. Development and assessment of healthy properties of meat and meat products designed as functional foods. Meat Sci. 95, 919-930. http://dx.doi.org/10.1016/j.meatsci.2013.03.030

Pappas, A.C., Zoidis, E., Papadomichelakis, G. \& Fegeros, K., 2012. Supranutritional selenium level affects fatty acid composition and oxidative stability of chicken breast muscle tissue. J. Anim. Physiol. An. N. 96(3), 385-94.

Pogorzelska-Nowicka, E., Atanasov, A.G., Horbańczuk, J. \& Wierzbicka, A., 2018. Bioactive compounds in functional meat products. Molecules 23, 307. DOI: 10.3390/molecules23020307

Raes, K., De Smet, S. \& Demeyer, D., 2004. Effect of dietary fatty acids on incorporation of long chain polyunsaturated fatty acids and conjugated linoleic acid in lamb, beef and pork meat: a review. Anim. Feed Sci. Tech. 113, 199221.

Raj, S., Skiba, G., Weremko, D., Fandrejewski, H., Migdał, W., Borowiec, F. \& Poławska, E., 2010. The relationship between the chemical composition of the carcass and the fatty acid composition of intramuscular fat and backfat of several pig breeds slaughtered at different weights. Meat Sci. 86, 324-330.

Saadoun, A. \& Cabrera, M.C., 2008. A review of the nutritional content and technological parameters of indigenous sources of meat in South America. Meat Sci. 80, 570-581. DOI: 10.1016/j.meatsci.2008.03.027

Sevon-Aimonen, M. L., Honkavaara, M. \& Serenius, T., 2007. Genetic variation of loin and ham quality in Finnish Landrace and Large White pigs. Agric. and Food Sci. 16, 89-102. Doi.org/10.2137/145960607782219328

Singh, M., 2005. Essential fatty acids, DHA and human brain. Indian J. Pediatr, $72,239$. Doi.org/10.1007/BF02859265

Skoufos, I., Tzora, A., Giannenas, I., Bonos, E., Papagiannis, N., Tsinas, A., Christaki, E. \& Florou-Paneri. P., 2016. Dietary inclusion of rapeseed meal as soybean meal substitute on growth performance, gut microbiota, oxidative stability and fatty acid profile in growing-fattening pigs. Asian J. Anim. Vet. Adv.1, 1-13. DOI: 10.3923/ajava.2016.89.97

Shi, Y., Li, X. \& Huang, A., 2019. A metabolomics-based approach investigates volatile flavor formation and characteristic compounds of the Dahe black pig dry-cured ham. Meat Sci. 158, 107904. https://doi.org/10.1016/j.meatsci.2019.107904

Sun, Y., Fu, M., Li, Z. \& Peng, X., 2017. Compounds released from pork by HS-SPME-GC-MS. Food Anal. Method. 11(5), 1321-1329.

Teye, G.A., Sheard, P.R., Whittington, F.M., Nute, G.R., Stewart, A. \& Wood, D., 2006. Influence of dietary oils and protein level on pork quality. 1. Effects on muscle fatty acid composition, carcass, meat and eating quality. Meat Sci. 73(1), 157-165.

Vandendriessche, F., 2008. Meat products in the past, today and in the future. Meat Sci. 78, 104-113. 
Venkateswaran V., Fleshner N.E. \& Klotz L.H., 2004. Synergistic effect of vitamin E and selenium in human prostate cancer cell lines. Prostate Cancer Prostatic Dis., 7(1), 54-56. Doi: 10.1038/sj.pcan.4500707

Wang, H., Wang, L.-S., Shi, B.-M. \& Shan, A.-S., 2012. Effects of dietary corn dried distiller's grains with solubles and vitamin $\mathrm{E}$ on growth performance, meat quality, fatty acid profiles, and pork shelf life of finishing pigs. Livest. Sci. 149, 155-166. Doi.org/10.1016/j.livsci.2012.07.009

Wettasinghe, M., Vasanthan, T., Temelli, F. \& Swallow, K., 2001. Volatile flavor composition of cooked by-product blends of chicken, beef and pork: a quantitative GC-MS investigation. Food Res. Intern. 34(2-3), 149-158. Doi.org/10.1016/S0963-9969(00)00146-0

Whitney, M.H., Shurson, G.C., Johnston, L.J., Wulf, D.M. \& Shanks, B.C., 2006. Growth performance and carcass characteristics of grower-finisher pigs fed high-quality corn distillers dried grain with solubles originating from a modern midwestern ethanol plant. Anim. Sci. J. 84(12), 3356-3363.

Wood, J.D., Richardson, R.I., Nute, G.R., Fisher, A.V., Campo, M.M., Kasapidou, E., Sheard, P.R. \& Enser, M., 2003. Effects of fatty acids on meat quality: a review. Meat Sci. 66, 21-32.

Wyrwisz, J., Półtorak, A., Zalewska, M., Zaremba, R., \& Wierzbicka, A., 2012. Analysis of relationship between basic composition, $\mathrm{pH}$, and physical properties of selected bovine muscles. B. Vet. I. Pulawy. 56, 403-409.

Xiao-Wei, H., Zhi-Hua, L., Xiao-Bo. Z., Ji-Jong, S., Han-Ping, M., Jie-Wen, Z., Li-Min, H. \& Holmes, M., 2016. Detection of meat-borne trimethylamine based on nanoporous colorimetric sensor arrays. Meat Sci. 197, 930-936.

Young, O.A., Berdagué, J.-L., Viallon, C., Rousset-Akrim, S. \& Theriez, M., 1997. Fat-borne volatiles and sheepmeat odour. Meat Sci. 45(2), 183-200.

Zhang, Y., Zhu, S., Wang, X., Wang, C. \& Li, F., 2011. The effect of dietary selenium levels on growth performance, antioxidant capacity and glutathione peroxidase 1 (GSHPx1) mRNA expression in growing meat rabbits. J. Anim. Feed Sci. 169(3-4), 259-264. 